\title{
Designing and manufacturing a solar rotary dryer for drying beef and studying its quality and storage characteristics
}

\author{
Hassan Hadi Mehdi Al-Rubai'ya, Mohammed Zyarah Eskandera, Khalid Hassak Abdul \\ Hassan $^{a}$, Yasir Hilal Al-Hashami ${ }^{b}$ \\ aDepartment of Food Science, College of Agriculture, University of Basrah, Iraq. \\ bUniversity of Al Jazeera, Wadmedani, Sudan.
}

ABSTRACT An indirect rotary solar dryer for drying beef has been manufactured and designed in the food engineering workshop at the College of Agriculture, Basrah University. The dryer contains a solar collector with a length of $1.70 \mathrm{~m}$, depth of $0.25 \mathrm{~m}$, and width of $0.30 \mathrm{~m}$, a chimney and tubular met at mesh. Also, the solar collector includes a drying tube that has a capacity of $5 \mathrm{~kg}$ and is made of galvanized iron. Throughout the study period, there was a significant increase in the solar radiation energy $(p<0.05)$ with daylight hours passed till 12:00 PM. In addition, the maximum level of solar energy has been $810.55 \mathrm{~W} / \mathrm{m}^{2}$, which is after that reduced to $680.10 \mathrm{~W} / \mathrm{m} 2$ at 4:00 PM. In the rotary solar dryer, the drying efficiency was $65.91 \%$ at $60{ }^{\circ} \mathrm{C}$ and decreased with the increase in drying temperature. In the drying tube, the average temperature reached $80^{\circ} \mathrm{C}$ at $1: 00 \mathrm{PM}$, while the air temperature was $43^{\circ} \mathrm{C}$. Unsalted and salted beef were dried with the use of a different period of storage $(0,14,28,42,56$, and 70$)$ days and various $\left(60,70\right.$, and $\left.80^{\circ} \mathrm{C}\right)$ to study their qualitative properties. The result indicated that there is a decrease in moisture content with the increase in drying time. Furthermore, the chemical composition related to dried unsalted and salted beef indicated that there is a decrease in moisture percentage. At the same time, there is an increased ash percentage, fat and protein after the process of drying. There is an increase in the moisture percentage throughout the periods of storage different from other percentages of the chemical composition, which have been reduced with the increase in the storage periods. It was shown via the results that there was a decrease in the rehydration with increasing the drying temperature values for unsalted and salted dried beef. Results have reported that there has been a decrease in microbial content regarding dried unsalted and salted beef. Also, it was shown by the results that the model of Artificial Neural Networks (ANNs) showed good results of predicted content of the moisture.

KEYWORDS: microbiological content; qualitative characteristics; solar energy.

Accepted May 10, 2021 Published online July 20, 2021

Cite this article: Al-Rubaiy et al. (2021) Designing and manufacturing a solar rotary dryer for drying beef and studying its quality and storage characteristics. Multidisciplinary Science Journal 3: e20210011 doi: 10.29327/multiscience.20210011.

\section{Introduction}

One of the oldest methods for preserving food was the drying process, which is most widely used because it is effective and cheap (Modi et al 2007). Humans were known for the natural sun drying process from the past, and the people of the Arab countries used it to dry and store vegetables and fruits (Al-Rubai'y et al 2020). Lasisi et al (2020) reported that low-moisture, high temperatures, great areas, long drying time and no rainy weather are needed with natural sun drying. In addition, the method of natural sun drying results in a few bad changes in the foodstuffs, and this is associated with various factors, including pollution with microorganisms, weather conditions, insects, and dust, this resulted in non-exploitation economically on a large scale (Darvish et al 2013). Doymaz et al (2016) estimated that the process of drying decreases the microbial load and leads to lighter weights and volumes, which reduces the transportation and storage costs. Gates (2015) stated that the drying process stops food spoilage by stopping bacteria, 
enzymes, and fermentation. The drying process makes dried foodstuffs lightweight, easy to store and prepare, as well as preserving their flavor and nutritional value (Tekin and Baslar 2018) and (Xu et al 2019).

Meat is a high-value food source that consumers well receive because it is a source of essential amino acids, minerals, and B-complex vitamins, the distinction of meat is the unique composition of its muscles. The distinctive structure and composition of muscle result in the characteristic properties of meat (Macrae et al 1997). Djordjevic et al (2017) confirmed that meat contains a high value of dietary protein, essential fatty acids, vitamins, and minerals, which in turn make meat a high-quality food. Connective tissues and fiber muscles are the major meat structures. A single muscle fiber includes various contractile and myofibrils elements sheathed via an endomysium, considered a composite structure of collagen fibers. A muscle is made up of muscle fibers' bundles, every one of the fibers (10 mm $-100 \mathrm{~mm})$ (Bailey et al 1989) holds together via a collagen network, referred to as perimysium, while the whole muscle structure holds via a network, referred to as epimysium (Flint et al 1994). Ofstad et al (1993) indicated that dried meat might change and greatly affected primary structures, which lead to a change in the quality of production. This change that occurs affects the moisture movement's direction inside the meat and a change in the drying curve. The water content in meat muscles comprises about $75 \%$ water, held via surface tension and capillary forces. Because of its nutrient composition and high-water activity, meat is susceptible to microbial spoilage (Casaburi et al 2015). Modi et al (2007) stated that the shelf life of dried meat increases with the increase in its water activity following the process of drying.

Some properties of dried meat are affected by the drying process, including the bulk density, shrinkage, and porous structure (Laopoolkit et al 2011). Doymaz et al (2016) indicated that the occurrence of a loss in flavor, color, and nutritional value (due to the loss of some vitamins and amino acids) due to the use of traditional thermal methods of drying, which lead to thermal decomposition of meat, which reduces the re-hydration ratio and drying rate. Thus, novel technologies must be utilized for obtaining high-quality dried meat as well as dried meat products. A study conducted by Baslar et al (2014) utilized an ultra-sonic vacuum drying approach for reducing the drying time of beef and chicken. The current drying approaches of ultrasound-assisted vacuum drying (USV), freeze-drying (FD), and vacuum drying (VD) have been utilized for drying minced meats (Aksoy et al 2019). A few other methods, like microwave, ultrasound, and radiofrequency, could be used to reduce the quality loss and drying time. (Aksoy et al 2019). In addition, dried meat is used as one of the aroma ingredients in many foods' production, like baby food, instant soup, for enhancing nutrition (Akhtar and Pandey 2015).

From the above, solar drying technology can be used as an alternative to traditional thermal methods or the use of electric heaters that may negatively affect the dried product. On the other hand, the solar collectors showed some advantages during the drying process by using indirect sunlight in the absence of oxygen in the drying rooms, which in turn Maintains the color and flavor of dried meat, as well as preventing the loss of its nutritional value (Al Rubai' y 2019). Pochont et al (2020) confirmed that solar dryer has superior quality in comparison with the natural sun drying. Solar energy is considered alternative and renewable energy, and it is environmentally friendly and does not cause any residual pollutants, as well as being cheap and clean energy. It is available in Iraq, especially in Basrah, as it reaches 14 hours in the summer and 12 hours in the winter. It converts solar radiation into thermal energy of up to $90{ }^{\circ} \mathrm{C}$. Solar collectors were used to drying different types of foods. The product is homogeneous without shrinkage and maintains its qualitative characteristics compared to other dryers such as electric dryers and natural sun drying (Al Rubai'y 2019). The present study aims to design and manufacture the rotary solar dryer for drying meat (the combined drying room and solar collector are independent of external conditions) and study some qualitative characteristics of meat before and after the drying process.

\section{Material and Methods}

A rotary solar dryer has been manufactured and designed in the food engineering workshop, Agriculture college, Basrah University. It was used for drying the beef, and this is composed of the following parts (Figure 1):

\section{Iron structure}

Two iron structure was manufactured from the angle iron, and the first iron structure was used to carry the solar collector. The second iron structure was used to carry the solar cell, with $0.05 \mathrm{~m} \times 0.05 \mathrm{~m}$ dimensions with a vertical base 
of $1.70 \mathrm{~m}$ length and a width of $0.30 \mathrm{~m}$. It was supported by a second base, a width of $0.30 \mathrm{~m}$, length of $1.60 \mathrm{~m}$, and a height of $1.00 \mathrm{~m}$ from behind and the height of $0.40 \mathrm{~m}$ on the front, which makes the structure takes the shape of the triangle and the corner and at a tilt angle of $30^{\circ}$ (Figure 1). This base is provided with four small tires, each $0.20 \mathrm{~m}$, for easy movement and transfer. To increase the durability of the iron structure, it was provided angular iron cutters for both structures.

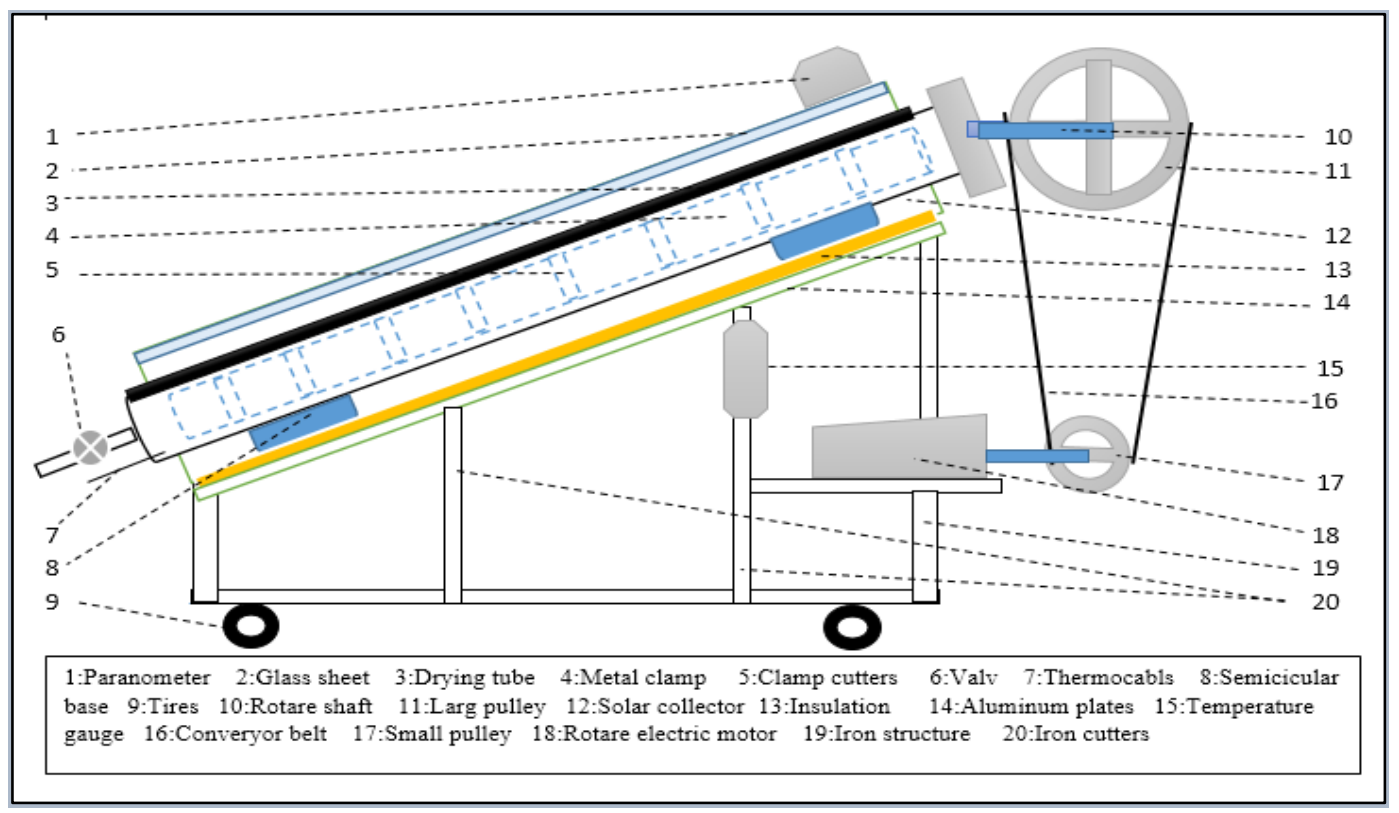

Figure 1 Layout of the solar rotary dryer.

\section{Solar collector}

The solar collector was manufactured for the rotary dryer. It supplied the needed thermal energy to reach the desired temperature. The solar collector consists of the following parts:

1 - Wooden structure: Whitewood was used in the manufacture of the wooden structure, which is a rectangular structure of $0.30 \mathrm{~m}$ width, $1.70 \mathrm{~m}$ length, $0.25 \mathrm{~m}$ depth, and the thickness of $0.015 \mathrm{~m}$. It's consisted of four wooden cutters, $0.30 \mathrm{~m}$ length, $0.15 \mathrm{~m}$ width, and thickness of $0.015 \mathrm{~m}$ to increase the durability of the wooden structure. The nearby base from the wooden cutters was covered with wooden plates of $1.70 \times 0.30 \mathrm{~m}^{2}$ diameter and thickness of $0.004 \mathrm{~m}$.

2 - The Insulation: A 0.05 m thickness of foam insulation was used to reduce the amount of heat loss from the solar collector. The essential function of using insulation was to isolate the drying tube from the outside and thus not to leak the heat energy acquired abroad (Al Rubai'y 2019). The insulator was placed inside the wooden structure at a height of $0.08 \mathrm{~m}$ from the base. It was proved by an internal wooden frame with special bolts. Internal cover made of reflective aluminum plates was put on the inter-insulator.

3 - Glass cover: Al Rubai'y (2019) used the normal glass for covering the solar collector with a thickness of $0.004 \mathrm{~m}$. Glass cover dimensions are $1.75 \times 0.25 \mathrm{~m}^{2}$. The glass cover was installed at $0.07 \mathrm{~m}$ from the absorption plate inside the wooden structure by Wooden framed with aluminum plates. White silicon was used as an adhesive for the glass cover and to prevent air from entering the vacuum.

4 - Drying room: A drying tube has been made of a galvanized iron tube with a length $1.85 \mathrm{~m}$, a thickness of $0.015 \mathrm{~m}$, and a diameter of $0.15 \mathrm{~m}$. It has two openings, the first on the far side is connected to a valve for drawing air, venting, and washing. The other opening on its upper side is attached to a movable and sealed cover. A large pulley was attached, which is connected by a conveyor belt to another small pulley connected to a rotating electric motor powered by power solar. The drying tube is supported on two radial piles in order to facilitate and balance its free rotation. The drying tube was painted from the outside in dark black with local dyes for increased absorption capacity of the incident solar radiation (Fig.1). A metal clamp was made of healthy iron with a circular section of $1.70 \mathrm{~m}$ in length and in diameter of $0.09 \mathrm{~m}$ the purpose of placing the meat to be dried in it. It is pushed into the drying tube and closed tightly. 
5 - Rotary electric motor: A German-origin Siemens rotary electric motor was used to move the drying tube by linking it to a conveyor belt and making the tube with a continuous rotational movement at a constant speed to ensure that all parts of the meat to be dried were dried.

6- The temperature gauge: The electronic temperature gauge of modal XMTD-2301 was used to measure the drying tube temperature, which is installed on the upper right side of the dryer with a double thermometer attached directly to the inter drying tube. A Constantine-copper thermocouples (made by Bollix England company) was distributed on the glass-covered and mercury thermometers were used to measure the ambient temperature.

7 - Solar radiation energy meter: The CM12-type of pyranometer (made by Kipp and Zonen, Holland company) was fixed on the upper left of the device and at a 30-degree angle for measuring the solar radiation's energy falling on solar collector surface and its readings were taken using a digital voltmeter. (Al Rubai'y 2019).

Beef with a weight of $2000 \mathrm{~g}$ and almost no grease was acquired from local markets in Basrah province. The samples have been transported to the Department of Food Sciences' food engineering laboratory in a refrigerated container. The beef was washed in tap water, cut into consistent and equal slices, and left at room temperature for 30 mins to remove as much moisture as possible. Some of the beef was unsalted, while others have been salted with a $\mathrm{NaCl}$ of $0 \%$. The beef was then weighed and dried using a solar rotary dryer. The temperature was measured with a mercury thermometer and thermocouple. The weight has been measured every 60 mins during the drying process at 3 different temperature degrees: 60,70 , and $80^{\circ} \mathrm{C}$. The moisture content (g water) according to dry weight (moisture content on dry weight $=$ moisture content $\% 100-$ moisture content $\%)$. All experimentations in this work have been carried out in triplicate. The following formula (Equation 1) was used to calculate the drying rate (Toledo 2007):

$$
D r=\frac{M_{t}+d_{t}-M_{t}}{d t}
$$

In which, $\mathrm{M}_{\mathrm{t}}$ represents the moisture content at $\mathrm{t}, \mathrm{M}_{\mathrm{t}}+\mathrm{d}_{\mathrm{t}}$ represents the content of moisture at $\mathrm{t}+\mathrm{dt}$, and $d t$ represents drying time ( $\mathrm{min}$.). In addition, the relative moisture in the drying room and outside has been measured via moisture device, the normal type (made by SOLARDO company, German) (Al Rubai'y 2019), with the use of ANN for the prediction of the moisture contents.

The efficiency of drying was assessed as follows in equation 2 (Toledo 2007):

$$
\eta=\frac{T_{d}-T_{o u t}}{T_{d}-T_{a}} \times 100
$$

In which, Td represents the temperature of the drying air, Tout represents outlet air temperature from the dryer, and Ta represents the temperature of the air. Following the process of drying, dried beef was put in vacuumed poly-ethylene bags and after that stored at $\left(25^{\circ} \mathrm{C}\right)$ for $0,7,14,21,28$, and 35 day-periods, which has been for dried and fresh samples throughout periods of storage. Also, the re-hydration process regarding the dried samples has been computed. A 2.0g of dried unsalted and salted beef has been put in a $500 \mathrm{ml}$ flask. After that, distilled water of $80 \mathrm{ml}$ at $30{ }^{\circ} \mathrm{C}$ has been added. Furthermore, the flask has been covered via a glass and after that boiled using a heater for 15 mins. Then, the sample has been left at room temperature for 2 hrs. The excess water has been filtered through a Buechner funnel employing Whatmann No4 filter paper. The filtration duration has been 1 min, while re-hydrated samples have been taken from the funnel and weighted after that. Equation 3 is used to calculate the re-hydration (Rangana 1976):

$$
R e=\frac{W_{r}}{W_{a d}} \times 100
$$

In which, $\mathrm{W}_{\mathrm{r}}$ represents the weight of the weight dried sample following re-hydration, and $\mathrm{W}_{\text {ad }}$ represents the weight of the weight dried sample prior to re-hydration (after drying).

\section{ANN modeling}

Multi-layered perception ANN has been utilized to predict the content of moisture (neuron output layer) and 3 neurons input layer (drying temperature and drying time) has been utilized. In this work, the SPSS Ver21 has been utilized. Forward BP network has been conducted for performing a suitable answer. The training process can be defined as a repetitive process consisting of the weights' changes between various layers in which throughout the training 
reaching gradually to the stability of such weight values, and error had occurred between predicted and experimental amounts was minimal. Furthermore, optimized conditions have been identified via the activation function (hyperbolic tan function) as it has been provided in equation 4 (Hernandez-Perez et al 2004):

$$
Y_{j}=\frac{2}{\left[1+\exp \left(-2 X_{j}\right)\right]}-1
$$

In which, $Y j$ represents the output, $X j$ represents the sum of weigh inputs regarding each neuron of layer j. $X_{j}$ has been computed based on equation 5 :

$$
X_{j}=\sum_{i=1}^{m} W_{i j} \times Y_{i}+b_{j}
$$

In which, $\mathrm{m}$ represents the number of the neurons of the output layer, $W_{i j}$ represents the weights between $\mathrm{j} \& \mathrm{i}$ layers, $Y_{i}$ represents the output of the $\mathrm{i}^{\text {th }}$ neuron, and $b_{j}$ represents the bias amount of the neuron of layer $\mathrm{j}$. $52.30 \%$ of the data for the process of the training and $16.80 \%$ for the testing. For obtaining a network with suitable topologies via algorithms of training, summation of square error (SSE) has been utilized to get minimized error and determine the significant independent variables (drying time and temperature). Figure 2 shows the model of ANN that has been utilized in moisture content modeling:

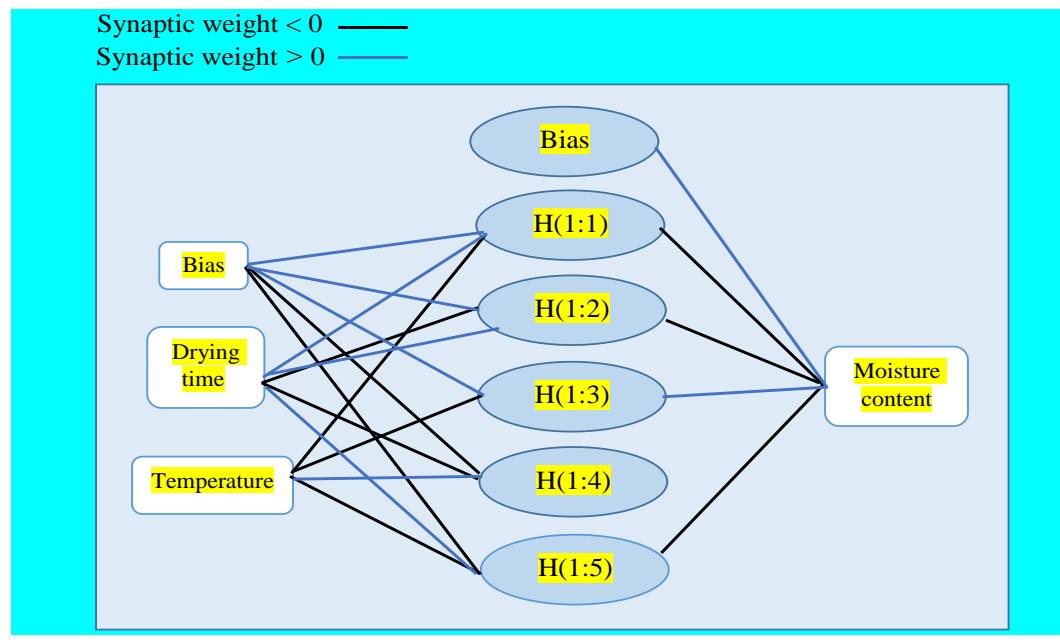

Figure 2 Hidden layer activation function: Hyperbolic tangent Output layer activation function: Identity.

\section{Drying mechanism using rotary solar dryer}

The rotary solar dryer is directed in the sun's direction at an angle of 30 degrees, and the device starts at 8 AM in the, but the setting of samples begins at 9 AM. The intensity of solar radiation and the percentage of moisture in the air and the drying room and fresh beef are measured. The air temperature and the temperature of the drying room are measured (periodically). After making sure of all the measurements, beef steaks is placed in the cylindrical clamp tightly, entered into the black drying chamber and closed all openings tightly. After that, a vacuum pump is attached to the air to draw the air from inside the drying room. After that, the rotary motor is started to make the drying chamber in a continuous rotational movement at a constant speed. To ensure the drying of all parts of the steaks, this rotational movement also helps not to collect water vapor on the inner walls of the drying room, and from time to time, the water vapor is withdrawn from the drying room by a vacuum pump. The drying process takes about 520 hours, and the temperature is controlled by placing an opaque cover over the reflector. The solar collector prevents the arrival of solar rays to it, and it is controlled manually. The reason behind the heating is that the vibrations happen in water molecules that have frequencies matching the solar radiation frequency. After that, moisture is evaporated from beef. After the drying process is completed, the dried meat is placed in vacuum bags of poly-ethylene, stored at room temperature, and then tested.

\section{Chemical tests}

This work examines the chemical composition related to beef and dried unsalted and salted beef. The moisture percentage has been evaluated using an electric oven at a temperature of $105^{\circ} \mathrm{C}$ till weight stability. Semi-micro Kjeldahl method was used to estimate the protein. A protein conversion factor (6.25) was used to estimate and multiply the 
total nitrogen. The fat percentage has been evaluated via the Soxhlet approach employing solvent petroleum ether with a range of boiling point that ranges in $\left(40\right.$ and $\left.60^{\circ} \mathrm{C}\right)$. For getting the white ash, the ash has been specified through burn beef sample in a Muffle furnace at a temperature of $550{ }^{\circ} \mathrm{C}$ (Egan et al 1988). Furthermore, pHmeter (Jenway 3505, Bibby Scientifics Ltd., U.K.) has been utilized for measuring the beef samples' pH. Also, beef samples of $10 \mathrm{~g}$ have been homogenized in distilled water of $100 \mathrm{ml}$ for 30 seconds (Rossini et al 2009).

\section{Microbial tests}

The microbiological tests have been conducted within sterilized and hygiene conditions. A $10.0 \mathrm{~g}$ has been weighed from various beef samples and a sterile dilution solution of $90 \mathrm{ml}(0.10 \%$ peptone) has been added within sterile settings. After that, samples were thoroughly mixed. In addition, a set of dilutions have been conducted within sterile settings. A dish-casting technique has been utilized for the cultured process. Microbial counts have been represented in the unit. The total bacteria counts have been evaluated using Nutrient Agar and subjected to incubation for $24 \mathrm{~h}-48 \mathrm{~h}$ at $32^{\circ} \mathrm{C}$. Total coliform bacteria have been evaluated utilizing MacConkey agar and subjected to incubation for $24-48$ hours at $37^{\circ} \mathrm{C}$. S. aureus was assessed using Mannitol salt Agar and subjected to incubation for 48 hours at 32 ${ }^{\circ} \mathrm{C}$, while the estimation of molds and yeasts was done via Potato Dextrose Agar and subjected to incubation for $24 \mathrm{~h}-96$ $\mathrm{h}$ at $25^{\circ} \mathrm{C}$. Andrews's approach was used for detecting Salmonella following activation via Tetrathionata broth at a temperature of $35{ }^{\circ} \mathrm{C}$ for 24 hours, after that cultured on the Agar media of the Salmonella Shigella and subjected to incubation for $24 \mathrm{~h}-48 \mathrm{~h}$ at $37^{\circ} \mathrm{C}$ (Andrews 1992).

\section{Statistical analyses}

A complete random design $(C R D)$ with $(2 \times 3 \times 7)$ factorial experimentation has been utilized. Also, the treatments were unsalted and salted beef, three drying temperature degrees, and seven periods of storage. Furthermore, data have been statistically analyzed with the use of SPSS Version 21. Furthermore, the comparison between means has been carried out using less significant difference (LSD) at a level of 0.05 .

\section{Results and discussion}

\section{Solar radiation energy}

Figure 3 shows the mean practical solar radiation energy recorded during the meat drying periods in the rotary solar dryer, as the results showed that the solar radiation energy increased significantly $(P<0.05)$ with daylight hours passed until 12:00 PM. The highest level of solar energy was $810.55 \mathrm{~W} / \mathrm{m}^{2}$ and then decreased to $680.10 \mathrm{~W} / \mathrm{m}^{2}$ at $4: 00$ PM. The reason for this difference is due to the solar angles (zenith, altitude, and azimuth) changed with daylight hours, The reduction of level to zero at midday and increase to maximum values at sunrise and sunset, as well as the angular change with daylight hours, the results agreed with the results with Al Hilphy (2013), Al Rubai'y (2019), Krauter and Ochs (2002), and Singh (2004) who asserted that solar radiation energy increases with daylight hours and reaches the maximum value at midday.

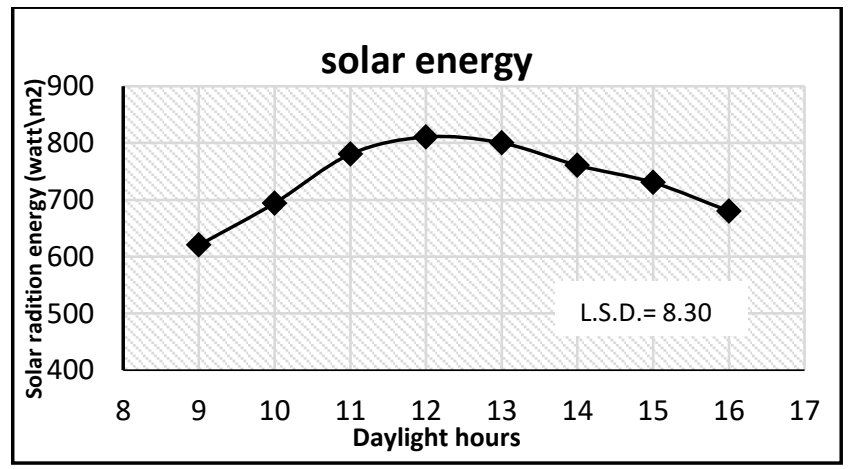

Figure 3 The mean of solar radiation energy during the daylight hours.

\section{Temperature drying}

Table 1 shows that the temperature drying has bee $(p \leq 0.05)$ increased significantly in the solar dryer with an increase in daylight hours and reached its maximum value at 1:00 PM the passing of daylight hours and reached the maximum value at $1: 00 \mathrm{PM}\left(80^{\circ} \mathrm{C}\right)$. Afterward, the temperature decreased due to the continued heat transfer to the 
drying tube which was isolated from external elements. The temperature was retained at 1:00 PM as a result of the heat gathered inside.

\begin{tabular}{ccc} 
Table 1 Recorded temperature of the atmosphere and solar rotary dryer during daylight \\
\cline { 2 - 3 } Time (hour) & $\begin{array}{r}\text { Temperature of the } \\
\text { atmosphere }\left({ }^{\circ} \mathrm{C}\right)\end{array}$ & $\begin{array}{c}\text { Temperature of the solar } \\
\text { rotary }\end{array}$ \\
\hline 9 & 28 & 45 \\
10 & 31 & 51 \\
11 & 36 & 65 \\
12 & 42 & 77 \\
13 & 43 & 80 \\
14 & 43 & 81 \\
15 & 40 & 78 \\
16 & 36 & 78 \\
Mean & 37.37 & 61.66 \\
L.S.D. & 3.4 & 3.6 \\
\hline
\end{tabular}

\section{Moisture content}

The two figures ( 4 and 5 ) exhibited the drying curve of beef (unsalted and salted) with various temperatures $\left(60,70\right.$, and $\left.80^{\circ} \mathrm{C}\right)$. Results have indicated that in all samples, moisture content was subjected to a significant gradual decrease $(p<0.050$ ) with increasing the drying time at various temperature degrees. There was a decrease in the moisture content from 3.78 g water.(g.d.b.) ${ }^{-1}$ (where d.b. is mean dry basis) in fresh fish to $0.21 \mathrm{~g}$ water.(g.d.b.) $)^{-1}$ in salted dried beef following 480 mins of the process of drying under $60{ }^{\circ} \mathrm{C}$. The time that is needed to dry the beef was 300 and 360 mins at 80 and $70^{\circ} \mathrm{C}$ temperatures, respectively. With regard to such conditions, there was a decrease in moisture content to 0.23 and $0.18 \mathrm{~g}$ water.(g.d.b. $)^{-1}$, respectively. With regard to unsalted beef, there was a decrease in moisture content and it took longer time. In fresh beef, there was a decrease in moisture content from $3.78 \mathrm{~g}$ water.(g.d.b.) ${ }^{-1}$ to 0.25 g water.(g.d.b.) $)^{-1}$ following drying for 540 mins with the use of $60^{\circ} \mathrm{C}$ for unsalted beef. Moreover, it has required $420 \mathrm{~min}$ and $360 \mathrm{~min}$ at $70^{\circ}$ and $80^{\circ} \mathrm{C}$, respectively. There was a decrease in moisture content to 0.23 and 0.20 g water.(g.d.b. $)^{-1}$, respectively. A study conducted by Patir et al (2006) reported that the reason for variations of the moisture content has been because of the duration of exposure and high temperature. The increase in temperature resulted in ionizing the molecules of the water and increasing their movements, thus, generated thermal energy, resulting in vapor pressure inside foodstuff and faster moisture evaporation with the increase in temperature. The process occurred at $80^{\circ} \mathrm{C}$ that has decreased drying time by 120 mins in comparison to $60^{\circ} \mathrm{C}$ and $70^{\circ} \mathrm{C}$. Furthermore, results have indicated that the process of drying that is related to salted beef has been fast compared to unsalted beef. This might be due to salt that drives internal moisture out of beef and transfer that moisture to beef's surface for evaporation. Results are in accordance with the results of Al Rubaiy et al (2020), when they performed drying of the Klunzinger's mullet fish.

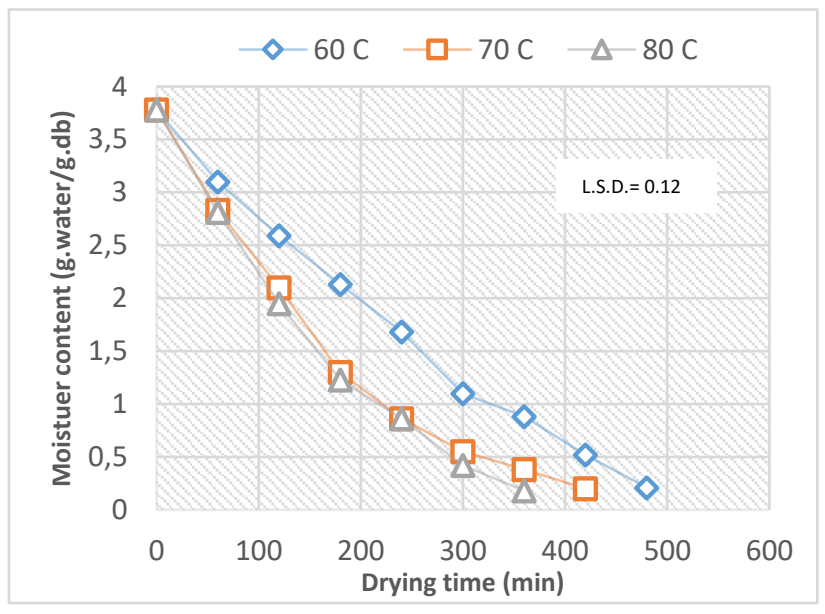

Figure 4 The drying curve of salted beef at different temperature.

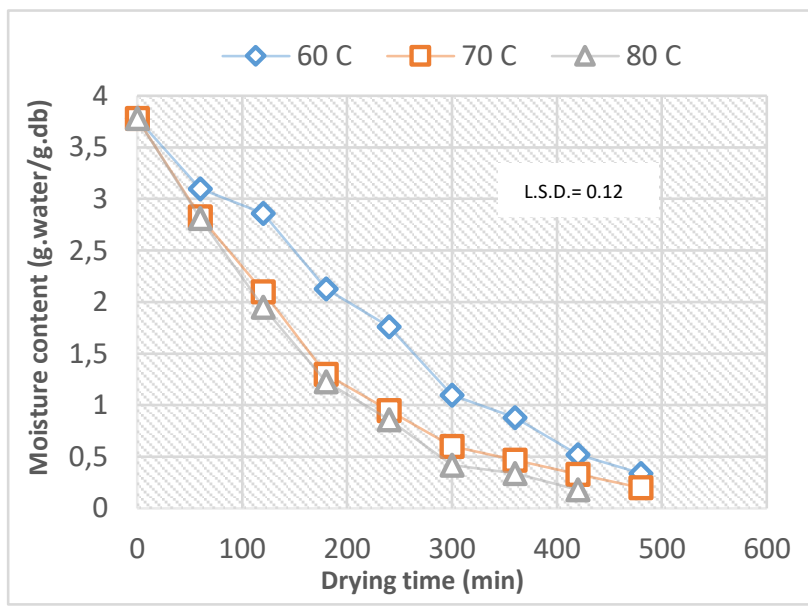

Figure 5 The drying curve of unsalted beef at different temperature. 


\section{Drying Rate}

Figures 6 and 7 have shown the curve of the drying rate regarding dried unsalted and salted beef at various temperatures $\left(60,70\right.$, and $\left.80^{\circ} \mathrm{C}\right)$. Also, results have indicated that the drying rate in all of the samples was decreased considerably $(p<0.05)$ with the increase in drying time at various temperatures. There was a decrease in the drying rate from $0.0991 \mathrm{~g}$ water/minute for fresh beef to $0.0023 \mathrm{~g}$ water/minute following $480 \mathrm{mins}$ of drying process at a temperature of $60{ }^{\circ} \mathrm{C}$ for the salted beef. Furthermore, the drying rate has reached 0.0014 and $0.0023 \mathrm{~g}$ water (min) ${ }^{-1}$ in the case where drying time has been $300 \mathrm{~min}$ and $360 \mathrm{~min}$ at 80 and $70{ }^{\circ} \mathrm{C}$. There was a decrease in the drying rate from $0.0990 \mathrm{~g}$ water/minute to $0.0034 \mathrm{~g}$ water/minute for fresh beef following drying process of $540 \mathrm{mins}$ at a temperature of $60^{\circ} \mathrm{C}$ for unsalted beef and reached 0.0018 and 0.0023 at 80 and $70{ }^{\circ} \mathrm{C}$ temperature, and it required 360 and 420 min., respectively. The reason for drying rate variations was because of the water in foodstuffs, which has been impacted via the duration of exposure and high temperature. A study conducted by (Lim et al 2020) reported that superheated steam drying generates a significantly shorter time of drying since the rates of drying have been higher.

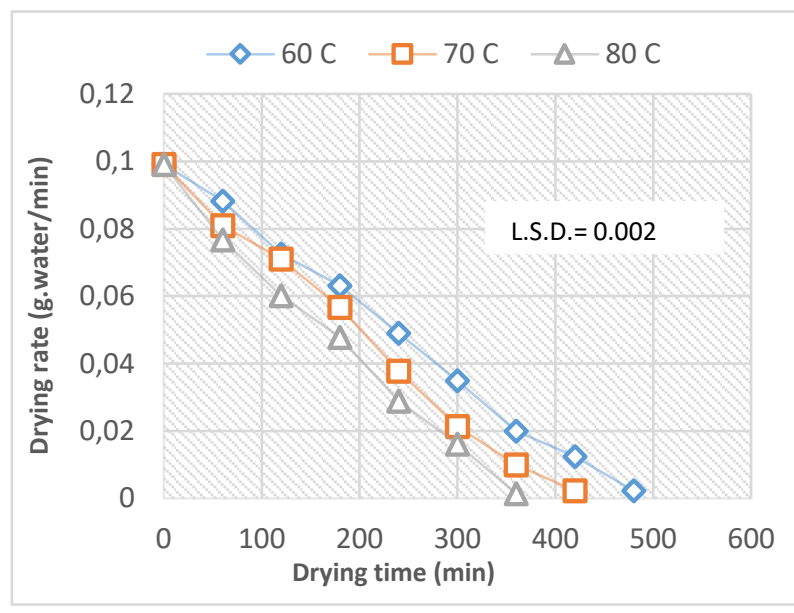

Figure 6 The drying rate curve of salted beef at different temperature.

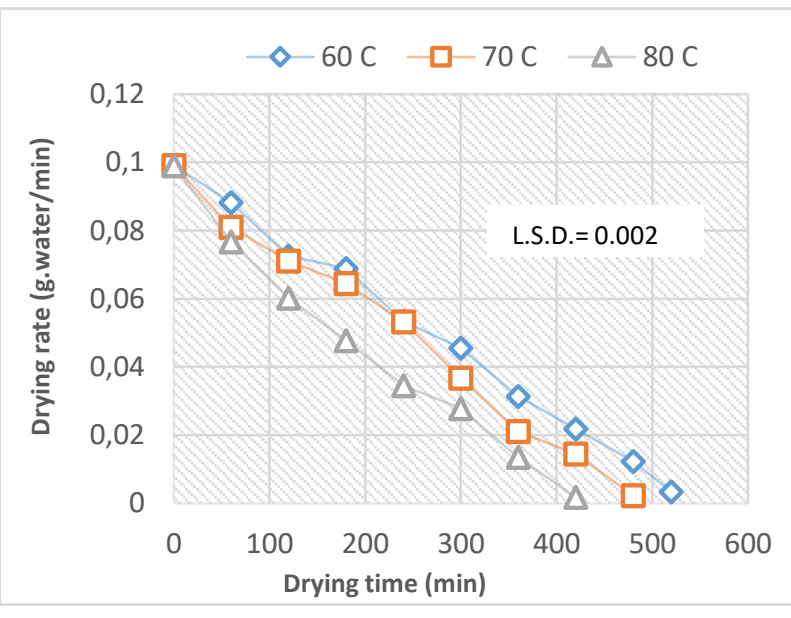

Figure 7 The drying rate curve of unsalted beef at different temperature.

\section{Drying efficiency}

The efficiency of the drying of dried beef with the use of a solar dryer at various temperatures is shown in Figure 8. It was shown by the results that there is a decrease in the drying efficiency with increasing the drying temperature due to increasing heat loss and increased temperature from the dryer. There was a decrease in the drying efficiency from $65.91 \%$ to $58.47 \%$, with the increase in temperature of drying from $60{ }^{\circ} \mathrm{C}$ to $80^{\circ} \mathrm{C}$. Also, the differences between this study and other studies might be due to the use of different dryers, i.e., this work utilized a rotary solar dryer, while others utilized hot air dryers, like Al-Hilphy and Al Rikabi (2013) reporting that the efficiency of the drying regarding strawberry with the halogen dryer was subjected to a decrease with the increase in drying temperature. In addition, a study conducted by Al Rubaiy et al (2020) reported a decrease in the drying efficiency of drying due to the increase in drying temperature.

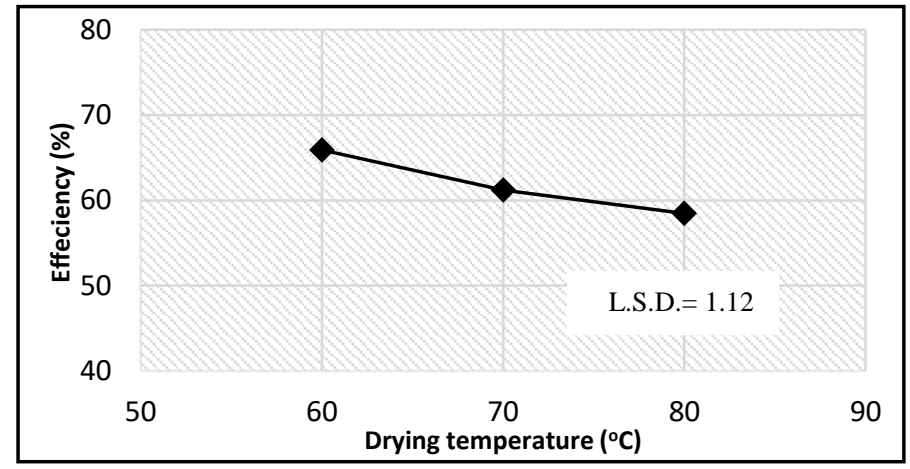

Figure 8 The drying efficiency of dried beef at different temperatures. 


\section{Artificial Neural Network (ANN) for modeling of moisture content}

To predict the moisture content of salted beef, ANN was used due to the fact that their qualitative properties are superior to the unsalted. Figure 9 shows the ANN results to predict moisture content regarding the salted beef versus the time of drying at various temperatures of drying. Also, results have reported that the predicted content of the moisture via ANNs has an excellent fit for the experimental data at all of the drying temperature degrees. In addition, the relation between experimental and predicted moisture content has been strong with $\mathrm{R} 2=0.968$, as shown in fig. (10). Furthermore, the model errors have been shown in table (2), in which the SSE for testing and training were 0.046 and 0.343 , respectively. Also, the relative errors of testing and training have been extremely small. Residual versus predicted moisture content via ANNs has been shown in fig 9. model can be considered as promising potential. Equations 6-8 indicate predicted contents of the moisture at drying temperature degrees between 60 and $80{ }^{\circ} \mathrm{C}$.

$$
\begin{gathered}
M C_{60}{ }^{\circ} \mathrm{C}=4 \mathrm{E}-09 \times 4-3 \mathrm{E}-06 \times 3+0.0006 \times 2-0.0622 \mathrm{x}+3.01 ; \mathrm{R}^{2}=0.968 \\
\mathrm{MC}_{70^{\circ} \mathrm{C}}=5 \mathrm{E}-09 \times 4-3 \mathrm{E}-06 \times 3+0.0006 \times 2-0.0621 \mathrm{x}+3.3981 ; \mathrm{R}^{2}=0.968 \\
\mathrm{MC}_{80^{\circ} \mathrm{C}}=7 \mathrm{E}-09 \times 4-4 \mathrm{E}-06 \times 3+0.0007 \times 2-0.0653 \mathrm{x}+3.3022 ; \mathrm{R}^{2}=0.968
\end{gathered}
$$

In which, MC represents the moisture content (g water/g d.b.), and $\mathrm{x}$ represents drying time (minute).

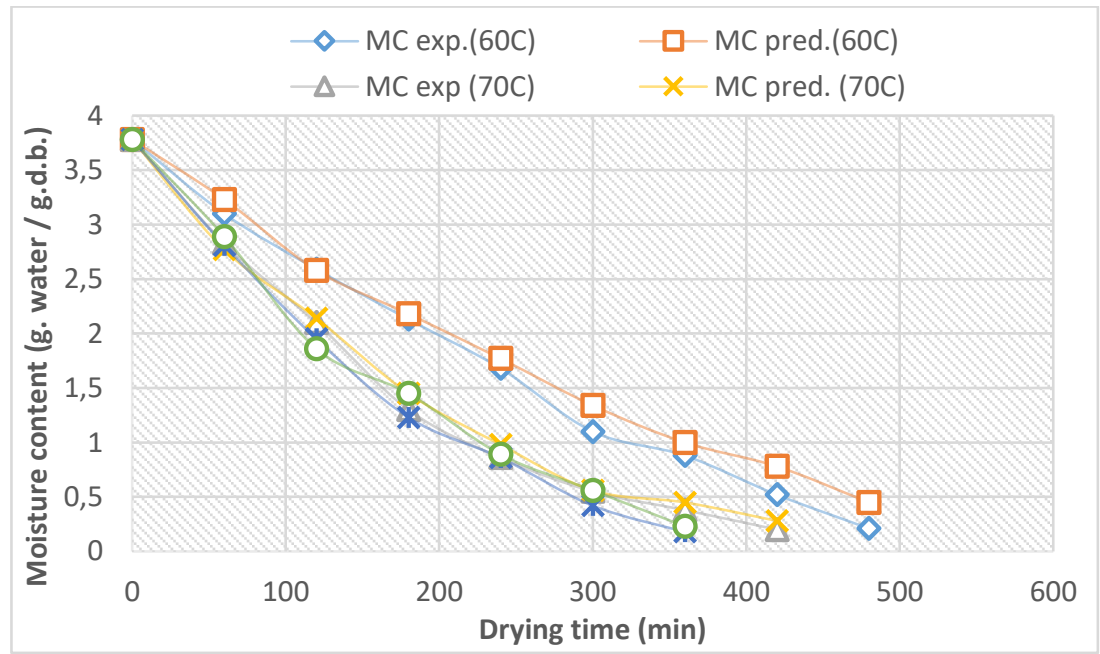

Figure 9 Results of ANN for predicting moisture content of beef at different drying temperatures. MC exp.: experimental Moisture content, MC pre.: predicted moisture content.

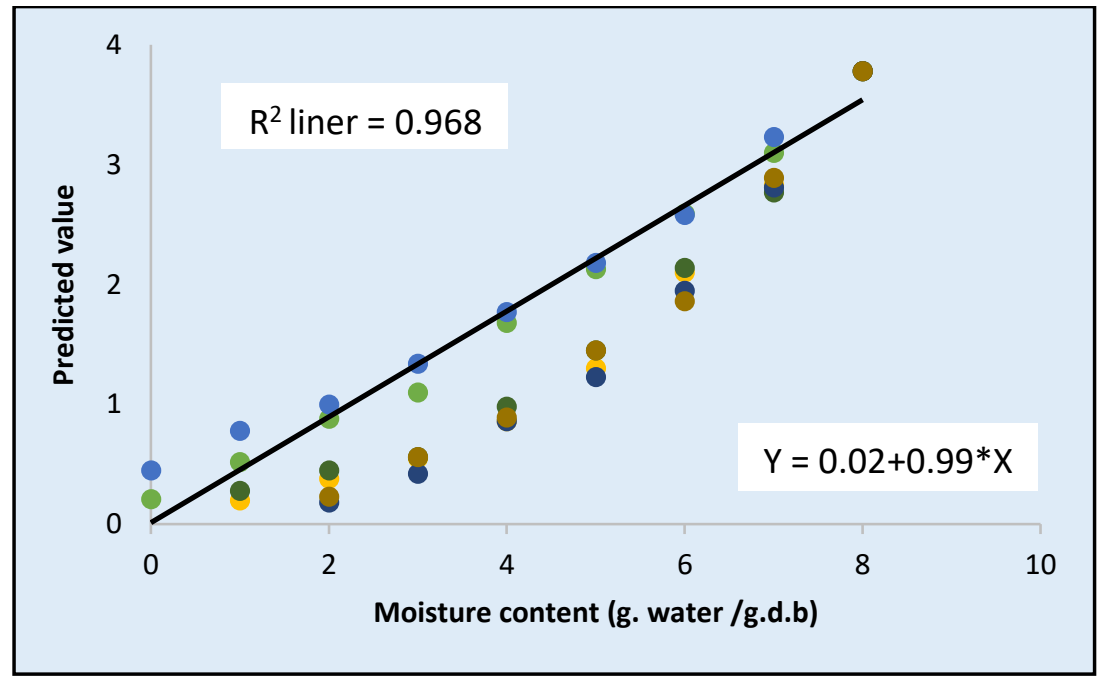

Figure 10 Results of ANN for predicting moisture content of beef vs. moisture content (experimental). 
Table 2 Model Summary, which was predicted by ANN.

\begin{tabular}{ccc}
\hline \multirow{2}{*}{ Training } & Sum of Squares Error & 0.343 \\
\cline { 2 - 3 } & Relative Error & 0.011 \\
\cline { 2 - 3 } Testing & Sum of Squares Error & 0.046 \\
\hline Holdont & Relative Error & 0.018 \\
\hline \multicolumn{2}{c}{ Relative Error } & 0.018 \\
\hline \multirow{2}{*}{ Error Computations are based on the testing sample } \\
\hline
\end{tabular}

\section{Chemical Content}

The results reported that the fresh beef's chemical content for protein, moisture, ash, and fat were 75.4, 18.4, 3.68 , and $2.52 \%$, respectively. These results are in accordance with the results obtained by Al Rubaiy (2016) and Jussara et al (2006), reporting that the beef's chemical content for moisture, protein, fat, and ash were 74.43, 19.1, 4.43, 1.12, and $74.48,17.22,2.08,1.21$. Also, the results indicated that there is a significant change $(p<0.05)$ in chemical content regarding dried unsalted and salted beef at various temperatures of 60,70 , and $80^{\circ} \mathrm{C}$ ) throughout periods of storage $(0,14,28,42,56$ and 70$)$ days. The variations in chemical contents' percentages were because of the different feeding and the age and variety of animals. The results reported that there was a significant reduction $(p<0.05)$ in moisture content with regard to all the samples with the increase in drying temperature degrees, which is different from other chemical composition percentages. These results are in accordance with the results of Al Temimi (2018) and Al Shaty et al (2014), reporting that there is a decrease in the moisture content, while there was an increase in other chemical composition percentages.

Table 3 indicates that moisture content (according to wet basis \%) witnessed a significant reduction $(p<0.05)$ with the increase in periods of drying at various temperature degrees for all of the samples. Results showed that there is a decrease in the moisture content from $75.40 \%$ in fresh beef to $21.89,20.22$, and $19.93 \%$ for dried salted beef at temperatures of 60,70 , and $80^{\circ} \mathrm{C}$, respectively, while for dried unsalted beef at identical temperatures, they have been $21.18,20.18$, and $20.12 \%$ respectively at 0 -days of the periods of storage. Results have reported that there is a slight increase in the content of the moisture throughout the period of storage. This is because of the differences in the moisture contents between beef and its surroundings that does not have much moist air, also the content of the moisture in outside air, since the bags of the packaging might be permeable to moisture, resulting in various molecular pressures and after that moisture that has been transferred from the outside air to the beef. Table 3 indicates that there is a significant increase in protein $(p<0.05)$ with the temperatures of drying. In other words, the protein's percentage in fresh beef has been increased from 18.40 to $59.30,60.20$, and $61.24 \%$ for dried salted fish at $60^{\circ}, 70^{\circ}$, and $80^{\circ} \mathrm{C}$ respectively, while, for dried unsalted beef at the same temperature degrees, they have reached $58.61,59.11$, and 60.18 $\%$ at 0 -days of the periods of storage.

In protein content, these variations are attributed to the heat that has resulted in the denaturing protein that decreased its water portability (Pattir et al 2006). These results are in accordance with the results of (Al Fadhly 2009), reporting that there is an increase in the protein content following the decrease in moisture for sun-dried and salted fish. Also, results showed that the protein content for dried unsalted and salted beef decreased with an increase in the storage periods because of minor moisture increase throughout the periods of the storage.

Table 3 indicated a significant increase in the fat content $(p<0.05)$ with the drying temperatures. There is an increase in the fat percentage from $3.68 \%$ in fresh beef to $15.76,15.40$, and $14.22 \%$ for dried salted beef at $60^{\circ}, 70^{\circ}$, and $80^{\circ} \mathrm{C}$ temperatures, while for dried unsalted beef were $15.46,15.10$, and $14.34 \%$ respectively at 0 -days of the periods of storage. These variations in the fat content might be attributed to moisture reduction due to the fact that the process of drying had impacted beef's chemical contents. These results are in accordance with the results of (Al Shatty et al 2014), stating that there was an increase in the percentage of fat following a decrease in dried salted fish moisture with the use of sun drying. A study conducted by (Tanujia et al 2020) reported that the content of fat regarding dried Anchovies (S. commersonii) had been $4.31 \%$ and $3.22 \%$ with the use of the solar dryer and open sun drying, respectively. Moreover, results have shown that the fat content for dried unsalted and salted beef has been decreased with an increase in storage periods. Table 3 shows a significant increase in the ash content $(p<0.05)$ with the drying temperatures. There is an increase in the ash percentage from $2.52 \%$ in fresh beef to $3.05,4.18$, and $5.60 \%$ for dried 
salted beef at $60,70,75$, and $80^{\circ} \mathrm{C}$, and for dried unsalted beef at identical temperatures have been $4.75,5.61$, and 5.63 $\%$ respectively at 0 -days of the periods of storage. In the ash content, these variations are attributed to the moisture decrease resulting from the salting and drying process. These results are in accordance with the results of (Al Shatty et al 2014), showing the increase in ash percentage after the decrease in the dried salted fish moisture via sun-drying. Results have indicated that there is a reduction in the ash content for dried unsalted and salted fish with increasing periods of storage as a result of the minor increases of the moisture throughout storage periods.

Table 3 Chemical composition of dried salted and unsalted beef at different temperatures during storage periods.

\begin{tabular}{|c|c|c|c|c|c|}
\hline \multirow{2}{*}{$\begin{array}{c}\text { Temperature } \\
\left({ }^{\circ} \mathrm{C}\right)\end{array}$} & \multirow{2}{*}{$\begin{array}{c}\text { Storage } \\
\text { periods (day) }\end{array}$} & \multicolumn{4}{|c|}{ Dried salted beef } \\
\hline & & Moisture (\%) & Protein (\%) & Fat (\%) & Ash (\%) \\
\hline \multirow{6}{*}{60} & 0 & $21.89 \pm 0.16$ & $59.30 \pm 0.15$ & $15.76 \pm 0.19$ & $3.05 \pm 0.20$ \\
\hline & 14 & $21.90 \pm 0.17$ & $59.30 \pm 0.16$ & $15.65 \pm 0.18$ & $3.15 \pm 0.21$ \\
\hline & 28 & $22.28 \pm 0.19$ & $59.28 \pm 0.19$ & $15.40 \pm 0.19$ & $3.04 \pm 0.20$ \\
\hline & 42 & $22.65 \pm 0.23$ & $59.11 \pm 0.13$ & $15.33 \pm 0.15$ & $2.91 \pm 0.19$ \\
\hline & 56 & $22.77 \pm 0.11$ & $59.00 \pm 0.14$ & $15.30 \pm 0.16$ & $2.93 \pm 0.18$ \\
\hline & 70 & $22.90 \pm 0.15$ & $58.97 \pm 0.16$ & $15.00 \pm 0.17$ & $3.13 \pm 0.20$ \\
\hline \multirow{6}{*}{70} & 0 & $20.20 \pm 0.18$ & $60.20 \pm 0.18$ & $15.40 \pm 0.14$ & $4.18 \pm 0.21$ \\
\hline & 14 & $20.43 \pm 0.16$ & $60.16 \pm 0.12$ & $15.35 \pm 0.11$ & $4.06 \pm 0.19$ \\
\hline & 28 & $20.66 \pm 0.22$ & $60.14 \pm 0.18$ & $15.26 \pm 0.16$ & $3.94 \pm 0.20$ \\
\hline & 42 & $20.74 \pm 0.11$ & $60.14 \pm 0.18$ & $15.13 \pm 0.22$ & $3.99 \pm 0.21$ \\
\hline & 56 & $20.85 \pm 0.18$ & $60.10 \pm 0.14$ & $15.13 \pm 0.19$ & $3.92 \pm 0.19$ \\
\hline & 70 & $20.01 \pm 0.19$ & $59.95 \pm 0.18$ & $15.10 \pm 0.18$ & $4.94 \pm 0.20$ \\
\hline \multirow{6}{*}{80} & 0 & $19.93 \pm 0.14$ & $61.24 \pm 0.12$ & $14.22 \pm 0.18$ & $5.61 \pm 0.19$ \\
\hline & 14 & $19.93 \pm 0.13$ & $61.24 \pm 0.13$ & $14.22 \pm 0.16$ & $4.61 \pm 0.18$ \\
\hline & 28 & $19.97 \pm 0.18$ & $61.14 \pm 0.17$ & $14.20 \pm 0.15$ & $4.69 \pm 0.19$ \\
\hline & 42 & $20.13 \pm 0.19$ & $61.10 \pm 0.19$ & $14.20 \pm 0.17$ & $4.57 \pm 0.20$ \\
\hline & 56 & $20.26 \pm 0.19$ & $60.97 \pm 0.16$ & $14.18 \pm 0.19$ & $4.71 \pm 0.21$ \\
\hline & 70 & $20.32 \pm 0.22$ & $60.86 \pm 0.19$ & $14.17 \pm 0.18$ & $4.65 \pm 0.20$ \\
\hline \multicolumn{2}{|c|}{ L.S.D. } & $0.15 \pm 0.06$ & $0.45 \pm 0.01$ & $0.32 \pm 0.04$ & $0.67 \pm 0.06$ \\
\hline \multirow{2}{*}{$\begin{array}{c}\text { Temperature } \\
\left({ }^{\circ} \mathrm{C}\right)\end{array}$} & Storage & \multicolumn{4}{|c|}{ Dried unsalted beef } \\
\hline & periods (day) & Moisture (\%) & Protein (\%) & Fat (\%) & Ash (\%) \\
\hline \multirow{6}{*}{60} & 0 & $21.18 \pm 0.18$ & $58.61 \pm 0.20$ & $15.46 \pm 0.21$ & $4.75 \pm 0.21$ \\
\hline & 14 & $21.47 \pm 0.18$ & $58.67 \pm 0.18$ & $15.32 \pm 0.19$ & $4.54 \pm 0.18$ \\
\hline & 28 & $21.69 \pm 0.20$ & $58.84 \pm 0.21$ & $15.20 \pm 0.18$ & $4.24 \pm 0.22$ \\
\hline & 42 & $21.78 \pm 0.21$ & $59.21 \pm 0.21$ & $15.18 \pm 0.19$ & $3.83 \pm 0.19$ \\
\hline & 56 & $21.92 \pm 0.22$ & $59.55 \pm 0.19$ & $14.92 \pm 0.20$ & $3.61 \pm 0.21$ \\
\hline & 70 & $22.12 \pm 0.19$ & $58.30 \pm 0.18$ & $14.80 \pm 0.21$ & $4.78 \pm 0.21$ \\
\hline \multirow{6}{*}{70} & 0 & $20.18 \pm 0.19$ & $59.11 \pm 0.20$ & $15.10 \pm 0.22$ & $5.61 \pm 0.19$ \\
\hline & 14 & $20.35 \pm 0.21$ & $59.08 \pm 0.20$ & $15.06 \pm 0.21$ & $5.51 \pm 0.19$ \\
\hline & 28 & $20.51 \pm 0.21$ & $58.94 \pm 0.22$ & $14.92 \pm 0.18$ & $5.63 \pm 0.20$ \\
\hline & 42 & $20.66 \pm 0.20$ & $58.88 \pm 0.19$ & $14.88 \pm 0.17$ & $5.81 \pm 0.20$ \\
\hline & 56 & $21.74 \pm 0.19$ & $58.82 \pm 0.19$ & $14.71 \pm 0.19$ & $4.74 \pm 0.19$ \\
\hline & 70 & $22.17 \pm 0.18$ & $58.61 \pm 0.22$ & $14.68 \pm 0.18$ & $4.54 \pm 0.21$ \\
\hline \multirow{6}{*}{80} & 0 & $20.12 \pm 0.18$ & $60.18 \pm 0.20$ & $14.34 \pm 0.19$ & $5.63 \pm 0.20$ \\
\hline & 14 & $20.41 \pm 0.19$ & $60.15 \pm 0.18$ & $14.30 \pm 0.21$ & $5.14 \pm 0.20$ \\
\hline & 28 & $20.55 \pm 0.21$ & $60.10 \pm 0.19$ & $14.21 \pm 0.21$ & $5.14 \pm 0.21$ \\
\hline & 42 & $20.63 \pm 0.19$ & $60.07 \pm 0.21$ & $14.18 \pm 0.19$ & $5.12 \pm 0.21$ \\
\hline & 56 & $20.73 \pm 0.22$ & $60.03 \pm 0.19$ & $14.15 \pm 0.14$ & $5.09 \pm 0.18$ \\
\hline & 70 & $20.87 \pm 0.21$ & $60.00 \pm 0.18$ & $14.10 \pm 0.15$ & $5.03 \pm 0.19$ \\
\hline \multicolumn{2}{|c|}{ L.S.D. } & $0.15 \pm 0.06$ & $0.45 \pm 0.01$ & $0.32 \pm 0.04$ & $0.67 \pm 0.06$ \\
\hline
\end{tabular}

The $\mathrm{pH}$ values

Figures 11 and 12 indicated the $\mathrm{pH}$ values for dried unsalted and salted beef with various temperatures throughout different periods of storage. Results have specified that $\mathrm{pH}$ related to dried salted beef has been $(5.95,6.11$ and 6.14$)$ at $\left(60,70\right.$, and $\left.80^{\circ} \mathrm{C}\right)$, respectively at 0 -days of the storage periods, has been $6.12,6.31$ and 6.35 respectively after a 70-day storage period. The $\mathrm{pH}$ values have been $5.79,6.05$, and 6.08 , respectively, at 0 -days of storage. It has reached 6.13, 6.30, and 6.34, respectively, after a 70-day storage period in dried unsalted beef. Results have exhibited 
an increase in the $\mathrm{pH}$ regarding dried unsalted and salted beef with the storage periods, while the salted beef $\mathrm{pH}$ was exceeded in comparison with unsalted beef. In addition, $\mathrm{pH}$ was increased due to the protein decomposition process continuation because of the continuation of the enzymatic activities, whether it has been microbial or intrinsic that results in a release and production of nitrogenous bases and amino acids, ammonia or urea, all that has resulted in increasing the value of the $\mathrm{pH}$. These results are in accordance with the results of Fath El Bab (2005), reporting that $\mathrm{pH}$ value was increased with the use of high salt concentration.

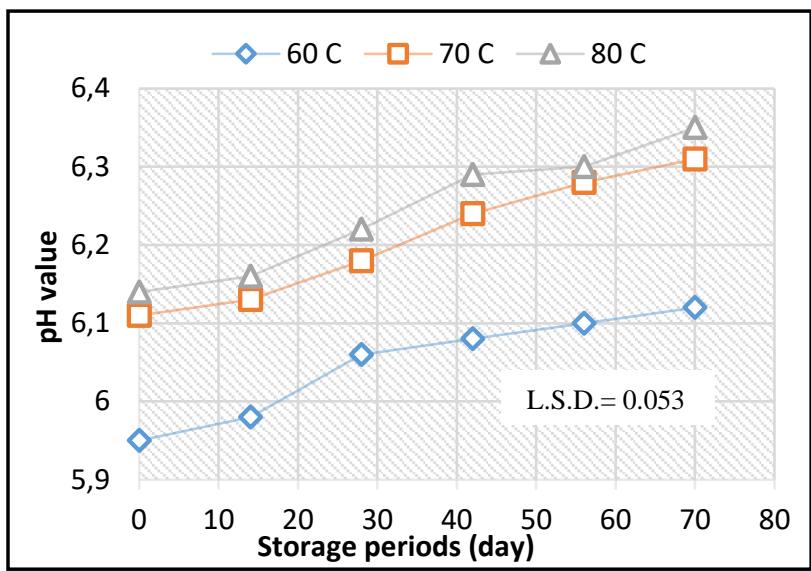

Figure $11 \mathrm{pH}$ value curve of salted beef at different temperature during different storage periods.

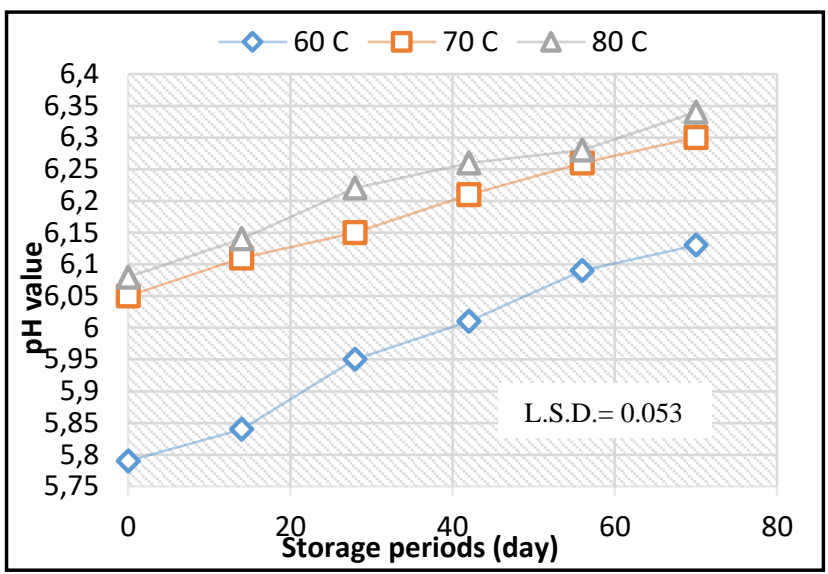

Figure $12 \mathrm{pH}$ value curve of unsalted beef at different temperature during different storage periods.

\section{Re-hydration}

The two figures (13 and 14) reported that there are re-hydration changes of dried unsalted and salted beef at various storage periods $(0,14,28,42,56,70)$ days and temperatures $(60,70$, and 80$)$. The results also reported that the dried salted beef re-hydration at $\left(60,70\right.$, and $\left.80^{\circ} \mathrm{C}\right)$ had been $1.87,1.84$, and $1.81 \%$, respectively, at 0 -days of the storage period. Then, there has been a decrease in the re-hydration as the storage periods increased till reaching (1.58, 1.54 , and 1.52 ) \%, respectively, following a 70-day storage period. These results reported that at the same temperature, the dried unsalted beef re-hydration had been $(1.74,1.79$, and $1.74 \%)$, respectively at 0 -days of the storage period. Also it has been $1.55,1.61$, and $1.6 \%$ respectively after a 70 -day storage period. This is because of the moisture absorption from the atmosphere and it had an impact upon the chemical composition. Results have reported that there is a decrease in the re-hydration with the increase in temperatures and that might be because of the increase in beef's surface hardening at high temperature and due to protein denaturation that has been attributed to high temperature and weakened the capability for the water carrying. Morinos-Kouris and Krokida (2003) have reported that the rehydration has been impacted via some factors, including composition porosity, cellular regulation, and mechanical characteristics for dried material, in addition to the approach of the drying.

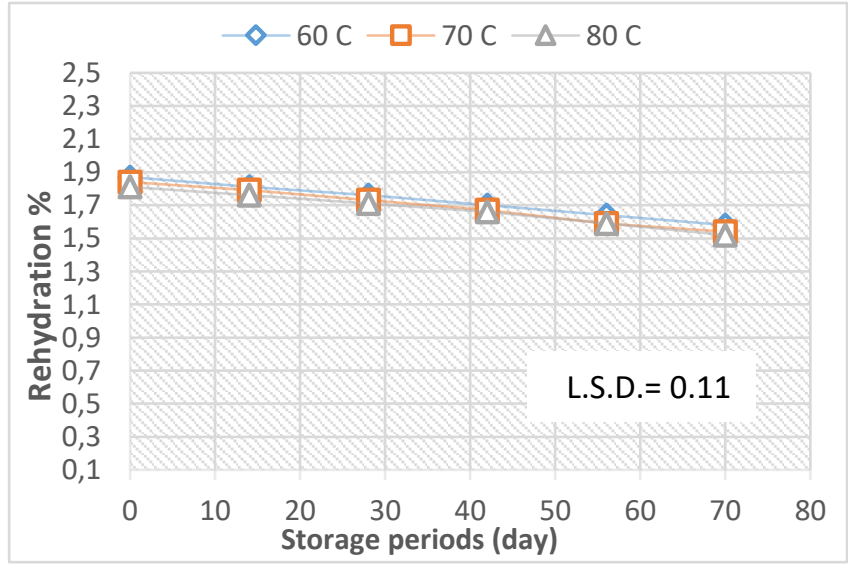

Figure 13 Rehydration value curve of salted beef at different temperature during different storage.

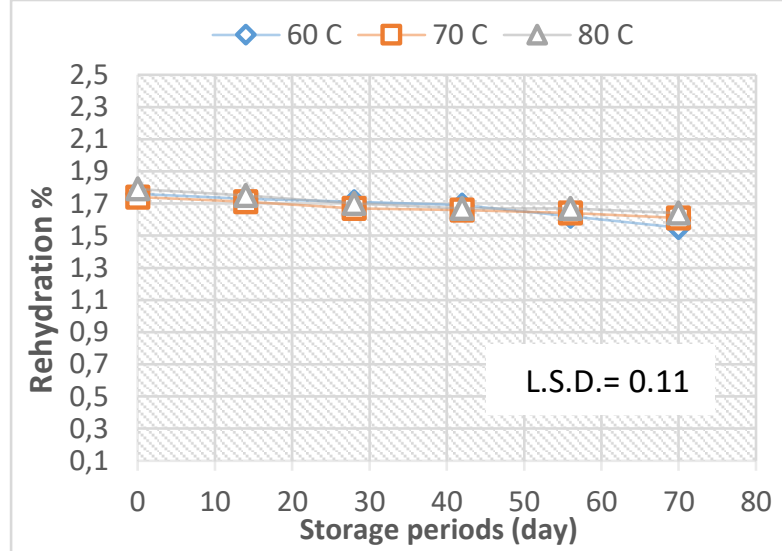

Figure 14 Rehydration value curve of unsalted beef at different temperature during different storage. 


\section{Microbial tests}

Table 4 indicated the microbial tests related to dried unsalted and salted beef at various storage periods $(0,14$, $28,42,56$, and 70 days) and temperatures $\left(60,70\right.$, and $\left.80^{\circ} \mathrm{C}\right)$. Also, the same table reported that the total bacterial count has been $8.00 \times 10^{3} \mathrm{cfu} . \mathrm{g}^{-1}$ and $6.00 \times 10^{3} \mathrm{cfu} . \mathrm{g}^{-1}$ in salted and unsalted fresh beef, respectively. A study conducted by Al Rubaiy (2016) and Kimiran et al (2014) specified that the total bacterial count had been $2.40 \times 10^{5} \mathrm{cfu} . \mathrm{g}^{-1}$ and $6.30 \times 10^{7}$ cfu. $\mathrm{g}^{-1}$ respectively in fresh beef. The results reported a decrease in the total count of the bacteria after drying in the salted beef to $1.31 \times 10^{3}, 1.22 \times 10^{3}$, and $0.960 \times 10^{3} \mathrm{cfu} . \mathrm{g}^{-1}$ at $60^{\circ}, 70^{\circ}$, and $80^{\circ} \mathrm{C}$ temperatures at 0 -days storage period, while the total bacterial count was $2.12 \times 10^{3}, 1.46 \times 10^{3}$, and $1.011 \times 10^{3} \mathrm{cfu}^{\mathrm{g}} \mathrm{g}^{-1}$ respectively following a 70 -day period of storage. Concerning unsalted beef, the total bacterial count was $3.46 \times 10^{3}, 2.90 \times 10^{3}$, and $2.10 \times 10^{3} \mathrm{cfu} . \mathrm{g}^{-1}$ at the same temperatures, respectively, at 0 -days of storage periods. At the same time, it had reached $4.12 \times 10^{3}, 3.10 \times 10^{3}$, and $2.25 \times 10^{3} \mathrm{cfu}^{-1} \mathrm{~g}^{-1}$, respectively, following a 70 -day period of storage. In addition, results have specified that total bacterial count has been increased in dried beef throughout storage due to the temperature of the storage. Results have been in accordance with the results of Al Temimi (2018), indicating that there is an increase in the total bacterial count in microwave-dried carp fish with an increase in the periods of storage. Table4 indicates that total coliform in salted fresh beef has been $0.60 \times 10^{3} \mathrm{cfu} . \mathrm{g}^{-1}$ and in unsalted fresh beef was $1.50 \times 10^{3} \mathrm{cfu} . \mathrm{g}^{-1}$.

Results have reported that there has not been any coliform growth in all the examined dried unsalted and salted beef samples. Al Rubaiy (2016) and Kimiran et al (2014) reported that the total coliform count had been $3.50 \times 10^{4} \mathrm{cfu} . \mathrm{g}$ ${ }^{1}$ and $1 \times 10^{6} \mathrm{cfu} . \mathrm{g}^{-1}$, respectively, in the fresh beef. Also, these results indicate that there is improved quality of health and without contaminated bacteria. Results were in accordance with the results of Nur et al (2020), reporting that total coliform count, total viable count, and fungal loads have been identified in the dry fish up $1.2 \times 103$ cfu. $\mathrm{g}^{-1}, 3.50 \times 105$ cfu. $\mathrm{g}^{-1}$, respectively. Table (3) indicated that there was an increase in the total number of molds and yeasts in beef. The total number of yeasts in salted fresh beef has been $1.10 \times 10^{2} \mathrm{cfu} . \mathrm{g}^{-1}$ and reduced after drying to $0.14 \times 10^{2}, 0.13 \times 10^{2}$, and $0.11 \times 10^{2} \mathrm{cfu} . \mathrm{g}^{-1}$ at $60^{\circ}, 70^{\circ}$, and $80^{\circ} \mathrm{C}$ at 0 -day of the storage periods, while the total number of yeasts gas been $0.26 \times 10^{2}, 0.25 \times 10^{2}$, and $0.17 \times 10^{2} \mathrm{cfu}^{-1}$ respectively after a 70 -day period of storage. In unsalted fresh beef, the total number of yeasts has been $2.30 \times 10^{2} \mathrm{cfu} . \mathrm{g}^{-1}$ and reduced to $0.16 \times 10^{2}, 0.16 \times 10^{2}$ and $0.13 \times 10^{2} \mathrm{cfu} . \mathrm{g}^{-1}$ after drying at identical temperatures respectively at 0 -day of the period of storage. The number of the yeasts has been $0.38 \times 10^{2}$, $0.27 \times 10^{2}$, and $0.26 \times 10^{2} \mathrm{cfu}^{-1} \mathrm{~g}^{-1}$ respectively after 70 days of storage.

Results have reported that the total number of the molds in the fresh salted beef has been $1.30 \times 10^{2} \mathrm{cfu} \cdot \mathrm{g}^{-1}$ and after drying, it was decreased to $0.26 \times 10^{2}, 0.24 \times 10^{2}$, and $0.26 \times 10^{2} \mathrm{cfu}^{-1} \mathrm{~g}^{-1}$ at $60^{\circ}, 70$, and $80^{\circ} \mathrm{C}$ at 0 -day of the period of storage, while the total number of molds have been $0.41 \times 10^{2}, 0.31 \times 10^{2}$, and $0.41 \times 10^{2} \mathrm{cfu}^{-1} \mathrm{~g}^{-1}$ after 70 -day storage period.

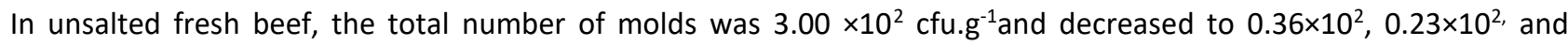
$0.21 \times 10^{2} \mathrm{cfu}^{-1} \mathrm{~g}^{-1}$ after drying at the same temperature degrees respectively at 0 -days of storage e period. This number of molds has been $0.49 \times 10^{2}, 0.35 \times 10^{2}$, and $0.28 \times 10^{2} \mathrm{cfu}^{-1} \mathrm{~g}^{-1}$, respectively, after 70 storage days. Kimiran et al (2014) and Al Rubaiy (2016) indicated that the total yeast and mold count had been $2.7 \times 10^{7} \mathrm{cfu}^{-\mathrm{g}^{-1}}$ and $1.3 \times 10^{3} \mathrm{cfu} . \mathrm{g}^{-1}$, respectively, in fresh beef. The reason for such an increase in the number of molds and yeasts in the dried beef can be a result of increases in the storage temperature, storage, and packaging. Results have been in agreement with the results that have been reported by Al Shaty et al (2014) who have noticed an increased number of molds and yeasts in the dried fish following the process of drying. Table (4) shows that the numbers of the $S$. aureus in the unsalted and the salted fresh beef have been $0.716 \times 10^{3} \mathrm{cfu} . \mathrm{g}^{-1}$ and $0.765 \times 10^{3} \mathrm{cfu} . \mathrm{g}^{-1}$, respectively.

Al-Rubai'y (2016) and Kimiran et al (2014) reported that the count of S. aureus count was $6 \times 10^{3} \mathrm{cfu} \cdot \mathrm{g}^{-1}$ and $6 \times 10^{5}$ cfu. $\mathrm{g}^{-1}$, respectively, in fresh beef. In addition, the results indicated a decrease in the count of $S$. aureus following drying in salted beef to $0.061 \times 10^{3}, 0.426 \times 10^{2}$, and $0.314 \times 10^{2} \mathrm{cfu} / \mathrm{g}^{1}$ at $(60,70$, and 80$){ }^{\circ} \mathrm{C}$ at 0 -day of periods of storage, while the total count of the $S$. aureus has been $0.065 \times 10^{3}, 0.439 \times 10^{2}$, and $0.325 \times 10^{2} \mathrm{cfu} \cdot \mathrm{g}^{-1}$ respectively following a 70 -day period of storage. With regard to unsalted beef, the total count of $S$. aureus was $0.065 \times 10^{3}, 0.446 \times 10^{2}$, and $0.329 \times 10^{2}$ cfu.g $\mathrm{g}^{-1}$ at the same temperature at 0 -day of storage, while it had reached $0.069 \times 10^{3}, 0.451 \times 10^{2}$, and $0.339 \times 10^{2}$ cfu. $\mathrm{g}^{-1}$, respectively, following 70 days storage. Results have reported that there is an increased total count of $S$. aureus in the dried beef throughout storage due to the storage temperature. Also, the results specified that there is a decrease in the numbers of S. aureus in dried salted beef in comparison to dried unsalted beef, which might be because of the salting 
method that made integrated hygienic conditions that result in decreasing the risks of $S$. aureus, which might lead to staphylococcal poisoning. These results are in accordance with the results of Al Fadheli (2009), reporting an increase in S. aureus in the dried Thelah fish (Scomberoides commersonnianus) with the use of a solar dryer. Furthermore, the results indicated that Salmonella doesn't exist in all beef samples, whether dried or fresh, since all microbes were eliminated via the drying process. All the standard specifications specified that Salmonella wasn't allowed in food (Stannard 1997).

Table 4 Microbial Tests (cfu/g) for fresh and dried salted and unsalted beef at different temperatures during storage periods.

\begin{tabular}{|c|c|c|c|c|c|c|}
\hline \multirow{3}{*}{$\begin{array}{c}\text { Drying } \\
\text { temperature }\left({ }^{\circ} \mathrm{C}\right)\end{array}$} & \multirow{3}{*}{$\begin{array}{l}\text { Storage } \\
\text { periods }\end{array}$} & \multicolumn{5}{|c|}{ Salted fresh beef } \\
\hline & & \multicolumn{5}{|c|}{ Microbiological content cfu.g-1 } \\
\hline & & Total bacteria & coliform & yeast & molds & Staph. aureus \\
\hline 25 & fresh beef & $6.00 \times 10^{3}$ & $0.60 \times 10^{3}$ & $1.10 \times 10^{2}$ & $1.30 \times 10^{2}$ & $0.716 \times 10^{3}$ \\
\hline \multirow{6}{*}{60} & 0 & $1.31 \times 10^{3}$ & 0 & $0.14 \times 10^{2}$ & $0.26 \times 10^{2}$ & $0.461 \times 10^{3}$ \\
\hline & 14 & $1.56 \times 10^{3}$ & 0 & $0.16 \times 10^{2}$ & $0.33 \times 10^{2}$ & $0.062 \times 10^{3}$ \\
\hline & 28 & $1.59 \times 10^{3}$ & 0 & $0.19 \times 10^{2}$ & $0.33 \times 10^{2}$ & $0.063 \times 10^{3}$ \\
\hline & 42 & $1.76 \times 10^{3}$ & 0 & $0.22 \times 10^{2}$ & $0.36 \times 10^{2}$ & $0.064 \times 10^{3}$ \\
\hline & 56 & $1.96 \times 10^{3}$ & 0 & $0.22 \times 10^{2}$ & $0.39 \times 10^{2}$ & $0.064 \times 10^{3}$ \\
\hline & 70 & $2.12 \times 10^{3}$ & 0 & $0.27 \times 10^{2}$ & $0.41 \times 10^{2}$ & $0.065 \times 10^{3}$ \\
\hline \multirow{6}{*}{70} & 0 & $1.22 \times 10^{3}$ & 0 & $0.13 \times 10^{2}$ & $0.24 \times 10^{2}$ & $0.426 \times 10^{2}$ \\
\hline & 14 & $1.26 \times 10^{3}$ & 0 & $0.15 \times 10^{2}$ & $0.25 \times 10^{2}$ & $0.428 \times 10^{2}$ \\
\hline & 28 & $1.31 \times 10^{3}$ & 0 & $0.19 \times 10^{2}$ & $0.27 \times 10^{2}$ & $0.435 \times 10^{2}$ \\
\hline & 42 & $1.36 \times 10^{3}$ & 0 & $0.19 \times 10^{2}$ & $0.27 \times 10^{2}$ & $0.435 \times 10^{2}$ \\
\hline & 56 & $1.41 \times 10^{3}$ & 0 & $0.23 \times 10^{2}$ & $0.29 \times 10^{2}$ & $0.437 \times 10^{2}$ \\
\hline & 70 & $1.46 \times 10^{3}$ & 0 & $0.25 \times 10^{2}$ & $0.31 \times 10^{2}$ & $0.439 \times 10^{2}$ \\
\hline \multirow{6}{*}{80} & 0 & $0.960 \times 10^{3}$ & 0 & $0.11 \times 10^{2}$ & $0.26 \times 10^{2}$ & $0.314 \times 10^{2}$ \\
\hline & 14 & $0.984 \times 10^{3}$ & 0 & $0.12 \times 10^{2}$ & $0.33 \times 10^{2}$ & $0.316 \times 10^{2}$ \\
\hline & 28 & $1.006 \times 10^{3}$ & 0 & $0.14 \times 10^{2}$ & $0.33 \times 10^{2}$ & $0.320 \times 10^{2}$ \\
\hline & 42 & $1.008 \times 10^{3}$ & 0 & $0.15 \times 10^{2}$ & $0.36 \times 10^{2}$ & $0.320 \times 10^{2}$ \\
\hline & 56 & $1.008 \times 10^{3}$ & 0 & $0.15 \times 10^{2}$ & $0.39 \times 10^{2}$ & $0.322 \times 10^{2}$ \\
\hline & 70 & $1.011 \times 10^{3}$ & 0 & $0.17 \times 10^{2}$ & $0.41 \times 10^{2}$ & $0.325 \times 10^{2}$ \\
\hline \multicolumn{2}{|l|}{ L.S.D. } & $0.34 \times 10^{3}$ & 0 & $0.05 \times 10^{3}$ & $0.05 \times 10^{3}$ & $0.030 \times 10^{3}$ \\
\hline \multirow{3}{*}{$\begin{array}{c}\text { Drying } \\
\text { temperature }\left({ }^{\circ} \mathrm{C}\right)\end{array}$} & & \multicolumn{5}{|c|}{ Unsalted fresh beef } \\
\hline & Storage & \multicolumn{5}{|c|}{ Microbiological content cfu.g ${ }^{-1}$} \\
\hline & & Total bacteria & coliform & yeast & molds & Staph. aureus \\
\hline 25 & fresh beef & $8.00 \times 10^{3}$ & $1.50 \times 10^{3}$ & $2.30 \times 10^{2}$ & $3.00 \times 10^{3}$ & $0.765 \times 10^{3}$ \\
\hline \multirow{6}{*}{60} & 0 & $3.46 \times 10^{3}$ & 0 & $0.16 \times 10^{2}$ & $0.36 \times 10^{2}$ & $0.066 \times 10^{3}$ \\
\hline & 14 & $3.66 \times 10^{3}$ & 0 & $0.19 \times 10^{2}$ & $0.38 \times 10^{2}$ & $0.066 \times 10^{3}$ \\
\hline & 28 & $3.87 \times 10^{3}$ & 0 & $0.22 \times 10^{2}$ & $0.41 \times 10^{2}$ & $0.067 \times 10^{3}$ \\
\hline & 42 & $3.93 \times 10^{3}$ & 0 & $0.32 \times 10^{2}$ & $0.43 \times 10^{2}$ & $0.067 \times 10^{3}$ \\
\hline & 56 & $4.10 \times 10^{3}$ & 0 & $0.37 \times 10^{2}$ & $0.46 \times 10^{2}$ & $0.068 \times 10^{3}$ \\
\hline & 70 & $4.12 \times 10^{3}$ & 0 & $0.38 \times 10^{2}$ & $0.49 \times 10^{2}$ & $0.069 \times 10^{3}$ \\
\hline \multirow{6}{*}{70} & 0 & $2.90 \times 10^{3}$ & 0 & $0.16 \times 10^{2}$ & $0.23 \times 10^{2}$ & $0.446 \times 10^{2}$ \\
\hline & 14 & $2.93 \times 10^{3}$ & 0 & $0.19 \times 10^{2}$ & $0.26 \times 10^{2}$ & $0.446 \times 10^{2}$ \\
\hline & 28 & $2.94 \times 10^{3}$ & 0 & $0.22 \times 10^{2}$ & $0.31 \times 10^{2}$ & $0.448 \times 10^{2}$ \\
\hline & 42 & $2.96 \times 10^{3}$ & 0 & $0.26 \times 10^{2}$ & $0.31 \times 10^{2}$ & $0.449 \times 10^{2}$ \\
\hline & 56 & $2.97 \times 10^{3}$ & 0 & $0.26 \times 10^{2}$ & $0.34 \times 10^{2}$ & $0.451 \times 10^{2}$ \\
\hline & 70 & $3.10 \times 10^{3}$ & 0 & $0.27 \times 10^{2}$ & $0.35 \times 10^{2}$ & $0.451 \times 10^{2}$ \\
\hline \multirow{6}{*}{80} & 0 & $2.10 \times 10^{3}$ & 0 & $0.13 \times 10^{2}$ & $0.21 \times 10^{2}$ & $0.329 \times 10^{2}$ \\
\hline & 14 & $2.11 \times 10^{3}$ & 0 & $0.16 \times 10^{2}$ & $0.22 \times 10^{2}$ & $0.329 \times 10^{2}$ \\
\hline & 28 & $2.13 \times 10^{3}$ & 0 & $0.17 \times 10^{2}$ & $0.25 \times 10^{2}$ & $0.331 \times 10^{2}$ \\
\hline & 42 & $2.15 \times 10^{3}$ & 0 & $0.21 \times 10^{2}$ & $0.25 \times 10^{2}$ & $0.336 \times 10^{2}$ \\
\hline & 56 & $2.21 \times 10^{3}$ & 0 & $0.22 \times 10^{2}$ & $0.27 \times 10^{2}$ & $0.337 \times 10^{2}$ \\
\hline & 70 & $2.25 \times 10^{3}$ & 0 & $0.26 \times 10^{2}$ & $0.28 \times 10^{2}$ & $0.339 \times 10^{2}$ \\
\hline L.S.D. & & $0.34 \times 10^{3}$ & 0 & $0.05 \times 10^{3}$ & $0.05 \times 10^{3}$ & $0.030 \times 10^{3}$ \\
\hline
\end{tabular}

Present challenges of rotary dryer solar 
In rotary dryer solar, the presented challenges have been the evaporated water existing from beef is condensate in dryer's inner wall and fall in beef's drying room and dust and clouds also collect, blocking the sun rays from reaching the solar collector, which decreases the efficiency of drying

\section{Conclusions}

The study found that using a locally manufactured rotary solar dryer in the drying process resulted in a short drying time and high efficiency. The findings revealed that as the temperature rose, drying efficiency decreased. In the drying process, salted beef dried faster than unsalted beef, according to the findings. According to the findings, the qualitative characteristics, chemical composition, and microbiological content of dried unsalted and salted beef changed throughout storage periods. The rate of re-hydration for dried salted and unsalted beef reduced at higher temperature degrees, according to the findings. For moisture content, ANN was given a good fit.

\section{Conflict of Interest}

The authors declare no conflict of interests.

\section{Acknowledgements}

We would like to thank the Department of Food Science, College of Agriculture, University of Basrah, for providing the laboratory and facilities to complete the research.

\section{References}

Akhtar J, Pandey RK (2015) Meat drying technology and drying characteristics of meat and meat products. International Journal of Applied And Pure Science and Agriculture. www.ijapsa.com.

Aksoy A, Karasu S, Akcicek A, Kayacan S (2019) Effects of Different Drying Methods on Drying Kinetics, Microstructure, Color, and the Re-hydration Ratio of Minced Meat. Foods J. DOI: 10.3390/foods806021.

Al-Hilphy AR (2013) A theoretical and practical study for the incident solar radiation intensity in the Basrah province (South of Iraq). IOSR Journal of Engineering 3:25-35.

AL-Rubai'y HH, Al-Shatty SM, Al-Hilphy AR (2020) Drying Klunzinger's mullet fish Planiliza klunzingeri using Halogen Dryer and modeling the moisture content with artificial neural network. Basrah J. Agric. Sci. DOI: 10.37077/25200860.2020.33.1.18

AL-Rubai'y HHM (2019) Designing and Manufacturing Tubular Solar Dryer for Drying Okra. Food Science and Quality Management J. DOI: 10.7176/FSQM. www.iiste.org

Al-Fadhly NKZ (2009) Salting and drying of the Thelah fish (Scomberoides commersonianus) and studying its quality characteristics using sensory, chemical, physical and microbial indices. M. Sc. Thesis, Coll. Agric., Univ. Basrah.

Al-Hilphy ARS, Al-Rikabi AKJ (2013) Mathematical modelling experimental study on thin layer halogen dryer of strawberry and study it is effect on antioxidant activity. Am. J. Agri. Biol. Sci. DOI: 10.3844/ajabssp.2013.

AL-Rubai'y HHM (2016) Designing , manufacturing and Evaluating the performance device for Removing Cholesterol and Fats from Minced meats, ph.D. Thesis, Coll.Agric., Univ. Basrah.

Al-Rubai'y HH, Abdul Hassan KH, Eskandder MZ (2020) Drying and salting fish using different methods and their effect on the sensory, chemical and microbial indices. Multidiscip. Rev. DOI: 10.29327/multi.2020003

Al-Shatty SMH, Al-Gwabrawy AA, Al-Hilphy ARS (2014) Study of chemical and microbiological characteristics of dried Cyprians carpio by vacuum solar dryer (Locally manufactured) (Part 2). Thi-Qar Univ. J. Agric. Res. 3:341-358.

Al-Temimi WKA (2018) Studying of physical and chemical properties and microbial content for dried fish by microwave. Diyala J. Agric. Sci. 10:12-28.

Andrews W (1992) Manuals of Food Quality Control, 4. Microbiological analysis. FAO Food and Nutrition paper No.14/4 (Rev.1), Rome: 347pp. http://www.fao.org/3/T0610E/T0610E.pdf

Bailey AJ, Light ND (1989) Connective Tissue in Meat and Meat Products; Elsevier Applied Science: London.

Baslar M, Kilicli M, Toker OS, Sagdic O, Arici M (2014) Ultrasonic vacuum drying technique as a novel process for shortening the drying period for beef and chicken meats. Innov. Food Sci. Emerg. Technol. 26:182-190.

Casaburi A, Piombino P, Nychas GJ, Villani F, Ercolini D (2015) Bacterial populations and the volatilome associated to meat spoilage. Food Microbiol. 45:83-102. 
Darvishi H, Azadbakht M, Rezaeiasl A, Farhang A (2013) Drying characteristics of sardine fish dried with microwave heating. J. Saudi Soc. Agric. Sci. 12:121-127.

Djordjevic J, Boskovic M, Dokmanovic M, Lazic I, Ledina T, Suvajdzic B, Baltic M (2017) Vacuum and Modified Atmosphere Packaging Effect on Enterobacteriaceae Behaviour in Minced Meat: Vacuum and Modified Atmosphere Packaging Effect. J. Food Process. Preserv. 41:e12837.

Doymaz I, Karasu S, Baslar M (2016) Effects of infrared heating on drying kinetics, antioxidant activity, phenolic content, and color of jujube fruit. J. Food Meas. Charact. 10:283-291.

Egan H, Kirk RS, Sawyer R (1988) Pearson's Chemical Analysis of Foods. 8th ed. Longman Scientific and Technical, The Bath Press, $591 \mathrm{pp}$.

Fath El-Bab GFA (2005) Health hazard associated with salted fish in Egyptian market. Egyp. J. Agric. Res. DOI: 10.1016/j.jssas.2012.09.002.

Flint O (1994) Food Microscopy: A Manual of Practical Methods, Using Optical Microscopy; Bios Scientific Publishers Ltd.: Oxford.

Gates KW (2015) Seafood processing: technology, quality and safety. J. Aquat. Food Product Technol. DOI: 10.1080/10498850.2014.954475.

Hernandez-Perez JA, Garcia-Alvarado MA, Trystram G, Heyd B (2004) Neural networks for the heat and mass transfer prediction during drying of cassava and mango. Innov. Food Sci. Emerg. Technol. DOI: 10.1016/j.ifset.2003.10.004.

Kimiran E, Saglam D, Ozer D, Ozcelik E (2014) Microbiological quality of minced meat samples marketed in Istanbul. YYÜ Vet Fak Derg., 25:67-70.

Krauter S, Ochs F (2002) An all - in - one solar home system, R10 02 - world climate and energy events, January 6-11, 2002.

Krokida MK, Morinos-Kouris D (2003) Re-hydration kinetics of dehydrated products. J. Food Eng. DOI: 10.1016/S02608774(02)002145.

Laopoolkit P, Suwannaporn P (2011) Effect of pretreatments and vacuum drying on instant dried pork process optimization. Meat Sci. 88:553-558.

Lasisi OI, Fapetu OP, Akinola AO (2020) Development of a solar dryer incorporated with a thermal storage mechanism. Dev. Int. J. Adv. Sci. Res. Eng. DOI: 10.31695/IJASRE.2020.33694

Macrae R, Robinson RK, Sadler MJ (1997) Encyclopedia of Food Science, Food Technology and Nutrition. Academic press Inc. 1456:2916-2934.

Modi VK, Sachindra NM, Nagegowda P, Mahendrakar NS, Narasimha Rao D (2007) Quality changes during the storage of dehydrated chicken kebab mix. Int. J. Food Sci. Technol. 42:827-835.

Nur IT, Ghosh BK, Acharjee M (2020) Comparative microbiological analysis of raw fishes and sun-dried fishes collected from the Kawran bazaar in Dhaka city, Bangladesh. Food Res. DOI: 10.26656/fr.2017.4(3).368.

Ofstad R, Kidman S, Myklebust R, Hermansson AM (1993) Liquid holding capacity and structural changes during heating of fish muscle: Cod (Gadus morhua L.) and salmon (Salmo salar). Food Structure 12:163-174.

Patir B, Gurelinanli A, Oksuztepe G, Irfan Ilhak O (2006) Microbiological and chemical qualities of salted grey mullet (Chalcalburnus tarichii Pallas, 1811). Int. J. Food Sci. Technol. DOI: 10.1016/j.sjbs.2017.04.003.

Pochont NR, Mohammad MN, Pradeep BT, Kumar PV (2020) A comparative study of drying kinetics and quality of Indian red chilli in solar hybrid greenhouse drying and open sun drying. Mater. Today Proc. 21:286-290. DOI: 10.1016/j.matpr.2019.05.433.

Rangana S (1976) Manual of Analysis of Fruit and Vegetable Products. 1st Edn., Tata MaGraw-Hill, New Delhi, 634pp.

Rossini K, Norena CP, Cladera-Olivera F, Brandelli A (2009) Casein peptides with inhibitory activity on lipid oxidation in beef homogenates and mechanically deboned poultry meat. LWT-Food Sci. Technol. 42:862-867. DOI: 10.1016/j.Iwt.2019.108633.

Singh S, Singh PP, Dhaliwal SS (2004) Multi-shelf portable solar dryer, Renewable energy 29:753-765.

Stannard C (1997) Development and use of microbiological criteria for foods. J. Food 122 Sci. Tech. DOI: 10.1.1.474.2198\&rep

Tanuja S, Mhatre CS, Mohanty G, Rout E, Rout P, Srivastava SK (2020) Development of low cost solar rack dryer and comparative biochemical quality evaluation of anchovies (Stolephorus commersonii) dried in sun and solar rack dryer. Int. J. Curr. Microbiol. App. Sci. DOI: 10.20546/ijcmas.2020.903.068.

Tekin ZH, Baslar M (2018) The effect of ultrasound-assisted vacuum drying on the drying rate and quality of red peppers. J. Therm. Anal. Calorim. 132:1131-1143.

Toledo RT, (2007) Fundamentals of Food Process Engineering. 1st edn., Springer, New York: 600pp. 
Xu L, Fang X, Wu W, Chen H, Mu H, Gao H (2019) Effects of high-temperature pre-drying on the quality of air-dried shiitake mushrooms (Lentinula edodes). Food Chem. 285:406-413. 